\title{
Differential Effects of a Vermicompost Fertilizer on Emergence and Seedling Growth of Tomato Plants
}

\author{
Yurdagül Şimşek-Erşahin ${ }^{*}$, Ali Ece², Ebru Karnez ${ }^{3}$ \\ ${ }^{I}$ Department of Biology, Science Faculty, Çankırı Karatekin University, 18200 Çankırl, Turkey \\ ${ }^{2}$ Program of Plant and Animal Production, Korkuteli Vocational School, Akdeniz University, 07800 Korkuteli/Antalya, Turkey \\ ${ }^{3}$ Department of Soil Science, Faculty of Agriculture, Çukurova University, 01100 Adana, Turkey
}

\begin{tabular}{l}
\hline A R T I C L E I N F O \\
Research Article \\
Received 01 August 2017 \\
Accepted 15 August 2017 \\
\hline
\end{tabular}

Keywords:

Organic fertilizer

Plant nutrition

Plant growth

Organic farming

Vermicomposting.

*Corresponding Author:

E-mail: yurdagulersahin@gmail.com

\begin{abstract}
A B S T R A C T
Vermicompost products have gained a great importance in plant nutrition over the years. They are reported to have plant growth promoting effects both in horticulture and field crops. The nutritional value and chemical properties of vermicomposts highly depend on the feedstock used in their production. The aim of this study was to evaluate vermicompost manure, derived from the mixture of cattle manure and kitchen scraps, on seed germination and growth of tomato seedlings (Lycopersicon lycopersicum Mill.). Four solid vermicompost amendment rates of 0,10,20, and 30\% were applied in plastic trays. Vermicompost application delayed and reduced seed emergence in all application rates, while in general, vermicompost substitution promoted growth tomato seedlings up to $20 \%$ of application rate. The results showed that vermicompost substitutions greater than $20 \%$ had adverse effects on seedling emergence and seedling growth parameters, which was attributed to high EC of vermicompost induced by cattle manure. Results suggest that both physical and chemical properties of the feedstock used for vermicompost production should be taken into consideration in order to sustain high vermicompost quality to ensure targeted plant growth for horticultural and agricultural purposes.
\end{abstract}

DOI: https://doi.org/10.24925/turjaf.v5i11.1360-1364.1458

\section{Introduction}

Vermicomposting has long been recognized as a low cost and environmentally sound process for treatment of many organic wastes such as animal manures, sewagesludge, crop residues, and industrial wastes (Albanell et al., 1988; Edwards and Burrows, 1988; Atiyeh et al., 2001; Edwards et al., 2004; Arancon et al., 2008; Lazcano and Dominquez, 2011).Vermicomposts are derived from the accelerated biological degradation of organic wastes by earthworms and microorganisms living in the vermicompost mixture. Vermicomposts are peat-like materials with excellent physical, chemical, and biological properties (Dominquez et al., 2010). There are numerous studies confirming that earthworm-processed organic wastes have growth promoting effects on a variety of crops in sgriculture, horticulture, and forestry (Edwards and Burrows, 1988; Edwards et al., 2004; Lazcano and Dominquez, 2011). Vermicompost promotes plant growth, enhances germination and increase yield in various vegetables, field crops, forest nursery plants and ornamentals.
Increased cost of environmentally safely managing of animal manures and increased prices of peat moss induced public to develop alternative ways, to process those wastes in a cost effective and environmentally sound way, and to gain materials to be used effectively in plant production. However, the side effect of these new alternative products should be assessed to ensure their beneficial use. Physical, chemical, and microbiological properties of end products in vermicomposting highly depend on many factors, including the type and properties of the initial waste materials used as feed stocks for vermicompost production. The objective of this study was to evaluate efficacy of vermicompost, produced from the mixture of cattle manure and kitchen scraps, in germination and growth of tomato seedlings (Lycopersicon lycopersicum Mill.) grown in plastic trays in greenhouse conditions. 


\section{Materials and Methods}

\section{Preparation of Vermicompost}

Vermicomposting feed stocks material was consisted of cattle manure, kitchen scraps, and card board. Separated cow manure was obtained from a local dairy operation farm (Cankiri, Turkey) where the barn is cleaned weekly by shovels. Manure was kept without treatment at least two months before its use for vermicomposting. Kitchen scraps (potato, green vegetables, cucumber, fruits, etc.) were provided by a local restaurant. Corrugated card board were shredded and used as the bedding material for the earthworms. The worm composting materials with the top layer (wetted shreds of card board) were mixed thoroughly by hand then earthworms Eisenia fetida (Savingy) were introduced.

The carbon to nitrogen $(\mathrm{C}: \mathrm{N})$ ratios of all worm composting materials were maintained between 20:1 to $25: 1$. Vermicomposting was carried out in a 1-m long by 1-m wide worm bed on a concrete floor at temperature varying between 20 and $30^{\circ} \mathrm{C}$. Initial stocking density for each batch was maintained between 2 and $3 \mathrm{~kg} \mathrm{~m}^{-2}$. Each worm bed was covered by a thick black plastic to protect worms from light and preserve the moisture inside. The worm bed was mixed manually every week throughout vermicomposting processes and watered with tap water as needed. The moisture content of the vermicomposting material was kept around field capacity to prevent nutrient loses by leaching. After 14 to 16 weeks of vermicomposting period, Vermicompost was made free of worms by inducing the worms to migrate to fresh waste material after 14 to 16 weeks of vermicomposting period. The vermicomposted material was left partially open at room temperature until to dry enough to be sieved using a chrome plated metal screen with $3 \mathrm{~mm}$ openings.

\section{Determination of The Vermicompost Properties}

Organic matter (OM) content was determined in a combustion oven $\left(550^{\circ} \mathrm{C}\right)$ as described by Nelson and Sommers (1982). Water content of vermicompost was determined by drying a five gram of fresh vermicompost in $105^{\circ} \mathrm{C}$ constant oven temperature. $\mathrm{EC}$ and $\mathrm{pH}$ were determined in one hour shaken slurries using a portable $\mathrm{EC}$ and $\mathrm{pH}$-meter in 1:5(v:v) and (1:2.5) vermicompost to $1 \mathrm{~N} \mathrm{KCl}$ mixtures, respectively. Total $\mathrm{N}$ content was determined by Kjeldahl method (Bremner and Mulvaney, 1982). Combustion at $550^{\circ} \mathrm{C}$ was performed to determine $\mathrm{C}: \mathrm{N}$ ratio of the vermicompost.

Cation exchange capacity of vermicompost was measured using ammonium acetate procedure as described by (Rhoades, 1982). Five grams of oven dry vermicompost was saturated with $1 \mathrm{~N}$ sodium acetate (pH7) then $1 \mathrm{M}$ ammonium acetate used to cast out sodium. The filtrates obtained from three repeats of the procedure described above were accumulated and analyzed for $\mathrm{Na}$ with a Flame Photometer. Micronutrient analysis of water extract of the vermicompost (vermicompost: distilled water $(1: 2, \mathrm{v} / \mathrm{v}))$, was carried out by Atomic Absorption Emission Spectrophotometer (Model: Varian Vista). The number of bacteria, actinomycetes and fungi in vermicompost were determined by plate count technique with application of selective media as described by Szczech (1999). The results were expressed as number of colony-forming units (cfu) per $1 \mathrm{~g}$ of vermicompost dried at $105^{\circ} \mathrm{C}$.

\section{Experimental Setup}

Tomato seeds (Lycopersicon lycopersicum Mill.) were obtained from a local market. Vermicompost was substituted for sphagnum peat in seed beds at rates of 0 , 10,20 , and $30 \%$ by volume. Individual seeds of tomatoes were sown as one seed per cell into each 85 cells of Styrofoam seedling trays filled with the corresponding vermicompost substitution rate. Seedling emergence was observed on all the cells of a tray. Thereafter, seedling emergence and seedling growth and development parameters were evaluated using fifteen randomly tagged seedlings from each of three replicates per treatment. In total, 45 samples/seedlings were examined for each treatment at the end of the sixth week after sowing. Seedlings were watered equally as needed. None of the chemical nutrients were used through the experiments. Trials were repeated two times (in 2013 and 2014). Seedling emergence time (ET; the time needed for the germination of $50 \%$ of the seeds) and seedling emergence rate (ER; the ratio of emerged seedlings over the total number of seeds sown) were observed. Shoot height $(\mathrm{mm})$, root length $(\mathrm{mm})$, shoot diameter $(\mathrm{mm})$, fresh and dry weights $(\mathrm{g})$, and leaf number were measured as seedling growth variables.

\section{Plant analysis}

The seedling samples were oven dried to constant weight at $65^{\circ} \mathrm{C}$ using a hot air oven (Scientific Series 2000). Total $\mathrm{N}$ content was measured according to Bremner and Mulvaney, (1982); total K content was measured according to Jones et al. (1956). For determination of micro-element content of the plant samples, $0.5 \mathrm{gr}$ of the plant sample was digested with the nitric acid $(10 \mathrm{~N})$ solution by boiling on a hot plate, which was then diluted to $50 \mathrm{ml}$ with distilled water and filtered through Whatman No.1. Samples were analyzed with an Atomic Absorption Emission Spectrophotometer (Model: Varian Vista)

\section{Statistical analysis}

Tray trials were repeated twice. The data were analyzed by one-way ANOVA to evaluate effect of vermicompost application rates on tomato seedling emergence and growth variables of root length, shoot height, number of leaves and shoot diameter. When the "zero hypothesis" was rejected in ANOVA, means for treatments were grouped by LSD procedure. Significance level of 5\% was considered in rejecting all zero hypothesis. 


\section{Results and Discussion}

Characteristics of The Vermicompost

$\mathrm{pH}$ and EC of the vermicompost, derived from the mixture of cattle manure and kitchen scraps, were high (Table 1), which could be attributed to the use of salt rocks as cattle feedstock by the local cattle hoarders. In this region, use of salt rocks as cattle feedstock is a common practice of growers. Total $\mathrm{N}$ and $\mathrm{P}$ contents of the vermicompost are quite low to support a vigorous plant development, while $\mathrm{K}$ and $\mathrm{Ca}$ contents are high, which would be derived from cattle manure (Table 1). Among the micronutrients, $\mathrm{Zn}$, and $\mathrm{B}$ contents of vermicompost are adequate and $\mathrm{Fe}, \mathrm{Mn}$, and $\mathrm{Cu}$ contents are not adequate (Table 2) to support plant growth.

Increased vermicompost application rates did not show a consistent positive effect across plant growth variables (Table 3). Greatest shoot height $(\mathrm{SH})$ occurred at no vermicompost application, while greatest root length (RL) occurred at $20 \%$ vermicompost. In general, $30 \%$ vermicompost resulted in decreased plant growth than $20 \%$ application rate, and this could be attributed to increased osmotic effect that influenced seedling growth adversely due to high electrical conductivity (EC) of the vermicompost (Table 2). Twenty percent vermicompost substitution provided the greatest values of RL, leaf number (LN), shoot diameter (SD), and dry weight (DW); while $30 \%$ vermicompost substitution resulted in the lowest growth parameters except in LN (Table 3). The highest vermicompost substitution decreased emergence rate (ER) as well.

\section{Plant Chemical Analyses}

Total $\mathrm{N}$ content of the seedlings were low in all treatments as expected because of the low $\mathrm{N}$ content of the vermicompost (Table 4). Similarly, K contents in seedlings were high in all rates of vermicompost applications as $\mathrm{K}$ content of the vermicompost was high. Adequate contents of $\mathrm{Fe}$ and $\mathrm{Zn}$ in seedlings revealed that plants could absorb these elements from the growth media in spite of high $\mathrm{pH}$. However, Ca content in seedlings showed that plants could not absorb this element even though $\mathrm{Ca}$ was present at adequate level in the vermicompost. On the other hand, accelerated contents of the $\mathrm{P}, \mathrm{Zn}$, and $\mathrm{Fe}$ in seedlings at $20 \%$ and $\% 30$ vermicompost indicated that vermicompost' chemical structure could support bioavailability of these nutrients even though their contents ( $\mathrm{Zn}$ and Fe) were not high enough in the vermicompost (Table 4). $\mathrm{Mn}$ and $\mathrm{Mg}$ contents of the seedlings were insufficient as their amounts were inadequate in both of vermicompost and the sphagnum peat.

Table 1 Some physical, chemical, and biological characteristics of the vermicompost used in experiments.

\begin{tabular}{l|c}
\multicolumn{1}{c}{ Characteristics of the vermicompost } & Value \\
\hline Organic matter content $(\%)$ & 45.0 \\
Total N content $(\%)$ & 1.72 \\
EC $\left.(\mathrm{dS} \mathrm{cm})^{-1}\right)$ & 6.0 \\
$\mathrm{pH}$ & 8.3 \\
$\mathrm{CEC}\left(\mathrm{cmol}_{\mathrm{c}} \mathrm{kg}^{-1}\right)$ & 52.35 \\
Moisture content $(\%)$ at saturation & 105.0 \\
C/N ratio & 15 \\
Total fungal colony $\left(\mathrm{CFU}\right.$ gdwt $\left.^{-1}\right)$ & $1.5 \times 10^{5}$ \\
Total bacterial colony (CFU gdwt $\left.{ }^{-1}\right)$ & $2.0 \times 10^{6}$ \\
Total actinomycetes colony $\left(\mathrm{CFU}\right.$ gdwt $\left.^{-1}\right)$ & $0.7 \times 10^{4}$ \\
\hline
\end{tabular}

Table 2 Micro element and heavy metal contents of the vermicompost used in experiments.

\begin{tabular}{l|cccccc}
\hline Macro elements $(\%)$ & $\mathrm{N}: 1.72$ & $\mathrm{~K}: 2.90$ & S: 0.006 & Ca: 7.24 & Mg: 1.15 & P: 0.8 \\
\hline Micro elements $\left(\mathrm{mg} \mathrm{kg}^{-1}\right)$ & Fe: 0.76 & Mn: 0.06 & B: 0.005 & Cu: 0.003 & Zn: 0.15 & Mo: 0.002 \\
\hline Heavy metals $\left(\mathrm{mg} \mathrm{kg}^{-1}\right)$ & Pb: 0.004 & Cd: 0.003 & Co: 0.002 & Ni: 0.004 & Cr: 0.003 & Al: 0.015 \\
\hline
\end{tabular}

Table 3 Seedling emergence and growth parameters as affected by vermicompost substitution rates in six week-old tomato seedlings.

\begin{tabular}{l|cccc}
\hline \multirow{2}{*}{ VR } & \multicolumn{4}{|c}{ Vermicompost substitution rates } \\
\cline { 2 - 5 } & 0 & 10 & 20 & 30 \\
\hline SH (mm) & $24.88^{\&}(4.23)^{\mathrm{a}}$ & $20.64(3.37)^{\mathrm{a}}$ & $24.08(2.41)^{\mathrm{b}}$ & $19.68(3.30)^{\mathrm{b}}$ \\
RL (mm) & $15.48(3.46)^{\mathrm{ab}}$ & $14.37(2.91)^{\mathrm{bc}}$ & $16.77(4.01)^{\mathrm{a}}$ & $13.31(2.74)^{\mathrm{c}}$ \\
SD (mm) & $3.20(0.30)^{\mathrm{a}}$ & $3.19(0.55)^{\mathrm{b}}$ & $3.58(0.39)^{\mathrm{b}}$ & $3.19(0.37)^{\mathrm{b}}$ \\
LN & $3.33(0.67)^{\mathrm{a}}$ & $3.04(0.56)^{\mathrm{a}}$ & $3.97(0.62)^{\mathrm{b}}$ & $3.95(0.67)^{\mathrm{c}}$ \\
FW (gr) & $58.38(5.32)^{\mathrm{a}}$ & $67.97(8.99)^{\mathrm{a}}$ & $66.51(11.66)^{\mathrm{a}}$ & $60.52(15.82)^{\mathrm{a}}$ \\
DW (gr) & $7.34(0.32)^{\mathrm{a}}$ & $8.27(0.93)^{\mathrm{a}}$ & $8.51(2.01)^{\mathrm{a}}$ & $5.98(1.69)^{\mathrm{a}}$ \\
ET (day) & $8(0.36)^{\mathrm{a}}$ & $10(0.23)^{\mathrm{b}}$ & $11(0.15)^{\mathrm{b}}$ & $11(0.24)^{\mathrm{b}}$ \\
ER (\%) & $95(0.14)^{\mathrm{a}}$ & $95(0.18)^{\mathrm{a}}$ & $95(0.12)^{\mathrm{a}}$ & $92(0.15)^{\mathrm{b}}$ \\
\hline
\end{tabular}

VR: Vermicompost ratio used for germination media. SH: Shoot height. RL: Root length. SD: Shoot diameter. LN: Leaf number. FW: Fresh weight. DW: Dry weight. ET: Time period as day that $50 \%$ of the seeds were germinated and seedling were emerged (day). ER: the ratio of emerged seedlings to the total number of seeds sown $(\%)$. \&: Means with different letters in the same Colum are different at the significance level of 0.05. Numbers in parentheses are standard deviations of the means. 
Table 4 Chemical nutrient contents of six week-old tomatoe seedlings.

\begin{tabular}{|c|c|c|c|c|c|c|c|c|c|c|}
\hline \multirow{2}{*}{ VR } & $\mathrm{N}$ & $\mathrm{P}$ & $\mathrm{K}$ & $\mathrm{Ca}$ & $\mathrm{Mg}$ & $\mathrm{Zn}$ & $\mathrm{Fe}$ & $\mathrm{Mn}$ & $\mathrm{Cu}$ & $\mathrm{B}$ \\
\hline & \multicolumn{5}{|c|}{$(\%)$} & \multicolumn{5}{|c|}{$\left(\mathrm{mg} \mathrm{kg}^{-1}\right)$} \\
\hline 0 & $1.54 \mathrm{D}$ & $0.35 \mathrm{D}$ & $5.32 \mathrm{~A}$ & $0.66 \mathrm{D}$ & $0.6 \mathrm{D}$ & $45.5 \mathrm{~A}$ & $184.3 \mathrm{~A}$ & $26.6 \mathrm{D}$ & $11.9 \mathrm{~A}$ & $31.9 \mathrm{~A}$ \\
\hline 0 & $1.68 \mathrm{D}$ & $0.34 \mathrm{D}$ & $4.97 \mathrm{~A}$ & $0.74 \mathrm{D}$ & $0.59 \mathrm{D}$ & $34.4 \mathrm{~A}$ & $219.9 \mathrm{~A}$ & $18.2 \mathrm{D}$ & $18.9 \mathrm{H}$ & $26.6 \mathrm{~A}$ \\
\hline 10 & $1.68 \mathrm{D}$ & $0.35 \mathrm{D}$ & $6.07 \mathrm{~A}$ & $0.71 \mathrm{D}$ & $0.55 \mathrm{D}$ & $43.4 \mathrm{~A}$ & $161.4 \mathrm{~A}$ & $24.2 \mathrm{D}$ & $19.5 \mathrm{H}$ & $30 \mathrm{~A}$ \\
\hline 10 & $1.4 \mathrm{D}$ & $0.38 \mathrm{D}$ & $6.31 \mathrm{~A}$ & $0.12 \mathrm{D}$ & $0.4 \mathrm{D}$ & $74.6 \mathrm{~A}$ & 194.9A & $29.4 \mathrm{D}$ & $28.8 \mathrm{H}$ & $26.7 \mathrm{~A}$ \\
\hline 10 & $1.4 \mathrm{D}$ & 0.38 & $6.49 \mathrm{~A}$ & $0.14 \mathrm{D}$ & $0.33 \mathrm{D}$ & $90.2 \mathrm{H}$ & $215.7 \mathrm{H}$ & $21.4 \mathrm{D}$ & $15.8 \mathrm{H}$ & $30.2 \mathrm{~A}$ \\
\hline 20 & $1.4 \mathrm{D}$ & $0.38 \mathrm{D}$ & $6 \mathrm{~A}$ & $0.1 \mathrm{D}$ & $0.3 \mathrm{D}$ & $90.9 \mathrm{H}$ & $209.1 \mathrm{H}$ & 16.1D & $12.1 \mathrm{H}$ & $36.8 \mathrm{~A}$ \\
\hline 20 & $1.75 \mathrm{D}$ & $0.4 \mathrm{~A}$ & $8.23 \mathrm{~A}$ & $0.12 \mathrm{D}$ & $0.28 \mathrm{D}$ & $96.7 \mathrm{H}$ & $282.2 \mathrm{H}$ & $24.4 \mathrm{D}$ & $12.4 \mathrm{H}$ & $36.5 \mathrm{~A}$ \\
\hline 20 & $1.75 \mathrm{D}$ & $0.41 \mathrm{~A}$ & 7.61A & $0.14 \mathrm{D}$ & $0.3 \mathrm{D}$ & $98.2 \mathrm{H}$ & $304.6 \mathrm{H}$ & $22.7 \mathrm{D}$ & $14.2 \mathrm{H}$ & $38.4 \mathrm{~A}$ \\
\hline 30 & $1.61 \mathrm{D}$ & $0.4 \mathrm{~A}$ & 7.17A & $0.13 \mathrm{D}$ & $0.25 \mathrm{D}$ & $101.2 \mathrm{H}$ & $282.3 \mathrm{H}$ & $21.2 \mathrm{D}$ & $8.2 \mathrm{~A}$ & $31.8 \mathrm{~A}$ \\
\hline 30 & $2.1 \mathrm{D}$ & 0.39 & $7.52 \mathrm{~A}$ & $0.09 \mathrm{D}$ & $0.23 \mathrm{D}$ & $113.2 \mathrm{H}$ & $185.5 \mathrm{H}$ & $19.5 \mathrm{D}$ & $14.4 \mathrm{H}$ & $33.4 \mathrm{~A}$ \\
\hline 30 & $1.96 \mathrm{D}$ & $0.42 \mathrm{~A}$ & $7.86 \mathrm{~A}$ & $0.09 \mathrm{D}$ & $0.24 \mathrm{D}$ & $139.8 \mathrm{H}$ & $235.2 \mathrm{H}$ & $22 \mathrm{D}$ & $7.9 \mathrm{~A}$ & $42.9 \mathrm{~A}$ \\
\hline 30 & $2.17 \mathrm{D}$ & $0.42 \mathrm{~A}$ & $7.78 \mathrm{~A}$ & $0.07 \mathrm{D}$ & $0.23 \mathrm{D}$ & $100.5 \mathrm{H}$ & $238.7 \mathrm{H}$ & 29.9D & $22.8 \mathrm{H}$ & $39.2 \mathrm{~A}$ \\
\hline
\end{tabular}

VR: Vermicompost rate used for germination media. A: Adequate, D: Deficient, H: High

Numerous studies have been conducted for evaluating plant growth promoting effect of vermicompost in ornamentals and horticultural and field crops (Arancon et al., 2006; 2005; 2004; Atiyeh et al., 2001; 2000; 1999; Lazcano and Dominquez, 2011). Most of these studies showed that vermicompost products have great potential in plant propagation and organic plant production. The plant growth promoting effect of vermicompost was suggested to be derived from its unique microbiological, chemical, and physical properties, resulting in increased enzymatic activities, increased numbers of beneficial microorganisms or biologically-active plant growthinfluencing substances such as plant growth regulators and humic acids, and improved physical structure of the container medium (Edwards et al., 2004; Lazcano and Dominquez, 2011).

In contrast to many literatures cited (Edwards and Burrows, 1988; Donald and Visser, 1989; Arancon et al., 2004; Edwards et al., 2004; Atiyeh et al., 2000; 1999; Lazcano and Dominquez, 2011), we observed differential effects of the vermicompost substitution on tomato seedlings. Emergence time (ET) and emergence ratio (ER) were affected adversely by the vermicompost, which would be resulted from its high $\mathrm{EC}$ and $\mathrm{pH}$ (Table 1). High $\mathrm{pH}$ inhibits uptake of many plant nutrients such as $\mathrm{P}, \mathrm{Mn}, \mathrm{Zn}, \mathrm{Cu}, \mathrm{Fe}$, and $\mathrm{B}$ (Diaz-Perez and CamachoFerre, 2010). In addition, $P$ content of the vermicompost was very low that would aggravate P deficiency in plants, reducing vermicompost utility for plant growth (Table 3). Plant growth is controlled by the most deficient nutrient in growth medium; therefore, we believe that $\mathrm{P}$ deficiency was the major growth limiting factor in our study besides high $\mathrm{pH}$ and EC (Sanchez, 2007). Even though vermicompost seemed to promote $\mathrm{P}$ bioavailability for seedlings grown $20 \%$ and $\% 30$ vermicompost (Table 4) (Arancon et al. 2004; Atiyeh et al., 2002) compared with the control, this increase in $\mathrm{P}$ content was not sufficient for an adequate seedling growth overall.

Vermicompost products are rich in humic acids compounds. Humic acids form complexes (chelates) with $\mathrm{Fe}, \mathrm{Al}$, and other cations which may explain the highest $\mathrm{Fe}$ contents in seedlings at $20 \%$ vermicompost rate, compared to the control (Table 4). High $\mathrm{pH}$ is known to inhibit $\mathrm{Fe}$ and $\mathrm{Cu}$ absorption in plants, however, seedlings grown in $20 \%$ vermicompost had greater $\mathrm{Fe}$ and $\mathrm{Zn}$ contents compared to the control, and this was attributed to complexation effect of humic acids that increased availability of $\mathrm{Fe}$ and $\mathrm{Zn}$ to tomato seedlings (Atiyeh et al., 2002b; Römheld and Nikolic, 2007).

Although concentrations of $\mathrm{Ca}$ and $\mathrm{Mg}$ in the vermicompost were adequate, their concentrations in plants were quite low, which would be resulted from high $\mathrm{K}$ concentration in vermicompost. $\mathrm{K}$ competes with $\mathrm{Ca}$ and $\mathrm{Mg}$ for plant uptake, known as ion antagonism or cation competition and it usually inhibits $\mathrm{Ca}$ and $\mathrm{Mg}$ uptake when its concentration is high enough in the solution (Carvajal et al., 1999).

Mn contents of tomato seedlings were low and this was attributed to its low concentration in vermicompost. In addition, high $\mathrm{pH}$ of the vermicompost could aggravate Mn deficiency of plants since manganese deficiency is most prevalent in calcareous soils, the $\mathrm{pH}$ of which varies from 7.3 to 8.5 (Humphries et al., 2007). On the other hand, elevated $\mathrm{Zn}$ contents of seedlings observed with increasing vermicompost substitutions might be due to high $\mathrm{Ca}$ concentration of vermicompost since it forms complexes with $\mathrm{CaCO}_{3}$ in alkaline soils with $\mathrm{pH} 8.2$ that promotes plant uptake of $\mathrm{Zn}$ (Storey and Anderson, 1970).

Our results revealed that quality of the vermicompost as affected by many factors including type and physical and chemical properties of the feed stocks used for vermicompost production is vital to sustain its plant growth promoting effect. Therefore, it is imperative that properties of feed stocks material must be reviewed carefully before their use in vermicompost production.

\section{Conclusion}

We evaluated plant nutritional value of a vermicompost produced from mixture of cattle manure and kitchen scraps (potato, green vegetables, cucumber, fruits, etc.). The vermicompost was highly affected by the feed stocks used in its production. High $\mathrm{pH}$ and EC were the principal determinants for its effects on emergence and growth parameters of the seedlings (Lycopersicon 
lycopersicum Mill.). In addition, the low $\mathrm{P}$ contents in tomato seedlings and vermicompost was also a major growth limiting factor in our study. Response of tomato seedlings to increasing vermicompost rates was inconsistent. In general, greatest growth promoting effect of vermicompost occurred with its $20 \%$ application rate. Further increases in vermicompost application rates resulted in reduced values of growth variables of root length, leaf number, and shoot diameter due to its high $\mathrm{pH}$ and EC.

Our results suggest that feed stocks materials used in vermicompost production should be selected properly to obtain a vermicompost with balanced nutrients and proper $\mathrm{pH}$ and EC needed for a vigorous plant growth. Therefore, future studies should proceed revealing the physical and chemical properties of the initial wastes (feed stocks) before vermicompost production to avoid a possible detrimental effect derived from high $\mathrm{pH}$ and EC of the final vermicompost product.

\section{Acknowledgments}

This study was supported by Scientifich Research and Project Comission (BAP) of Çankırı Karatekin University under the project number BAP/2011/31.

\section{References}

Albanell E, Plaixats J and Cabrero T. 1988. Chemical changes during vermicomposting (Eisenia fetida) of sheep manure mixed with cotton industrial wastes. Biol. and Fertility of Soils, 6: pp 266-269.

Arancon NQ, Edwards CA, Babenko A, Cannon J, Galvis P and Metzger JD. 2008. Influences of vermicomposts, produced by earthworms and microorganisms from cattle manure, food waste and paper waste, on the germination, growth and flowering of petunias in the greenhouse, Applied Soil Ecology 39, pp 91-99.

Arancon NQ, Edwards CA and Bierman P. 2006. Influences of vermicomposts on field

strawberries: Part 2. Effects on soil microbiological and chemical properties. Bioresource Technology, 97, 831-840.

Arancon NQ, Edwards CA, Bierman P, Metzger JD and Lucht C. 2005. Effects of vermicomposts produced from cattle manure, food waste and paper waste on the growth and yield of peppers in the field. Pedobiologia, 49: 297-306.

Arancon NQ, Edwards CA, Atiyeh RM and Metzger JD. 2004. Effects of vermicompost produced from food waste on the growth and yields of greenhouse peppers. Bioresource Technology 93: 139-144.

Atiyeh, R.M., Arancon, N., Edwards, C.A. and Metzger, J.D. 2002a. The influence of earthworm-processed pig manure on the growth and productivity of marigolds. Bioresource Technology 81, 103-108.

Atiyeh RM, Lees S, Edwards CA, Arancon NQ, Metzger JD. 2002 b. The influence of humic acids derived from earth worm processed organic wastes on plant growth. Bioresource Technology, pp 84: 7-14

Atiyeh, R.M., Arancon, N.Q., Edwards, C.A. and Metzger, J.D. 2000. Influence of earthworm- processed pig manure on the growth and yield of green house tomatoes. Bioresource Technology 75, 175-180.
Atiyeh, R.M., Edwards, C.A., Subler, S. and Metzger, J.D. 2001. Pig manure vermicompost as a component of a horticultural bedding plant medium: Effects on physicochemical properties and plant growth. Bioresource Technology 78, 11-20.

Atiyeh, R.M., Subler, S., Edwards, C.A. and Metzger, J. 1999. Growth of tomato plants in horticultural media amended with vermicompost. Pedobiologia, 43, 724-728.

Bremner JM and Mulvaney DCS. 1982. Total N. In: Page AL. (Edt.) Methods of Soil Analysis. Part 2, Chemical and microbiological analysis, ( $2^{\text {nd }}$ ed.). Madison, USA. American Society of Agronomy and Soil Science Society of America, pp: 595-622.

Carvajal M, Martıñez V, and Cerda A. 1999. Influence of magnesium and salinity on tomato plants grown in hydroponic culture. J. Plant Nutr. 22:177-190.

Diaz-Perez M, Camacho-Ferre F. 2010. Effect of composts in substrates on the growth of tomato transplants. HortTechnology; Vol 20 (2): pp 361-367

Donald DGM and Visser LB. 1989. Vermicompost as a possible growth medium for the production of commercial forest nursery stock. Appl. Plant Sci. 3, pp.110-113.

Domínguez J, Aira M, and Gómez Brandón M. 2010. Vermicomposting: earthworms enhance the work of microbes. In: H. Insam, I. Franke-Whittle and M. Goberna, (Eds.), Microbes at Work: From Wastes to Resources, Springer, Berlin Heidelberg, pp. 93-114

Edwards CA and Burrows I. 1988. The potential of earthworm composts as plant growth media. In: C.A. Edwards and E.F. Neuhauser (Eds). Earthworms in Waste and Environmental Management. pp. 211-219. SPB Academic Publ. Co. The Hague, Netherlands.

Edwards CA, Domínguez J and Arancon NQ. 2004. The influence of vermicomposts on plant growth and pest incidence. In: S.H Shakir and W.Z.A. Mikhaïl, (Eds). Soil Zoology for Sustainable Development in the 21st century. pp 397-420, Cairo.

Humphries JM, Stangoulis JCR, and Graham RD. 2007 Mangenese. In: Handbook of Plant Nutrition. Eds. Barker AV and Pilbeam DJ.Taylor and Francis, New York, USA, pp. 351-369

Jones JB, Wolf B, and Mills A. 1956. In Plant Analyses Hank Book (1st ed.). Micro Macro Publishing Inc. Athens, GA, pp 134-167.

Lazcano, C. Domínguez, J. 2011. The use of vermicompost in sustainable agriculture: impact on plant growth and soil fertility. In: Soil nutrients (Book). Nova Publishers, USA. ISBN: 978-161324-785-3.

Nelson DW and Sommers, LE.1982. Total Carbon, Organic Carbon, and Organic Matter. In: Page AL. (Edt.) Methods of Soil Analysis. Part 2, Chemical and microbiological analysis, $\left(2^{\text {nd }}\right.$ ed.). Madison, USA. American Society of Agronomy and Soil Science Society of America, pp:539-577.

Rhoades JD. 1982. Cation exchange capacity. In: Page AL. (Edt.) Methods of Soil Analysis. Part 2, Chemical and microbiological analysis, ( $2^{\text {nd }}$ ed.). Madison, USA. American Society of Agronomy and Soil Science Society of America, pp: 149-157.

Römheld V and Nikolic M. 2007. Iron. In: Handbook of Plant Nutrition. (Eds.) Barker AV. and Pilbeam DJ.Taylor and Francis, New York, USA, pp 329-345

Schulte EE and Hopkins BG. 1996. Estimation of Soil Organic Matter by Weight Loss-On-Ignition. Doi:10.2136/sssaspecpub46.c3. SSSA Special Publication, Soil Organic Matter: Analysis and Interpretation, 46:21-31

Storey JB and Anderson WB. 1970. Pecan Zinc Nutrition Research. Texas Agric Expt Station Progress Report 2710.

Szczech, MM. 1999. Suppressiveness of Vermicompost against Fusarium Wilt of Tomato. Journal of Phytopathology, 147 (3): $155-161$ 